AGRICULTURE AND BIOLOGY JOURNAL OF NORTH AMERICA

ISSN Print: 2151-7517, ISSN Online: 2151-7525, doi:10.5251/abjna.2012.3.7.296.301

(C) 2012, ScienceHuß, http://www.scihub.org/ABJNA

\title{
Problems and prospects of cassava production in Rivers State, Nigeria: A case study of Oyigbo local government area
}

\author{
${ }^{1}$ A. G. lyagba* and ${ }^{2}$ S.O.Anyanwu
}

${ }^{1}$ Department of Crop Science, Rivers State University of Education, Port Harcourt, Nigeria.

${ }^{2}$ Department of Agricultural Economics \& Extension, Rivers State University of Education, Port Harcourt, Nigeria. *Corresponding E-mail: apegragba@yahoo.com

\begin{abstract}
Cassava farmers generally are confronted with a lot of challenges especially in the Niger Delta. This study therefore examined the problems and prospects of cassava production in Oyigbo L.G.A. Multistage sampling technique was used in the data generation exercise. Six (6) villages were randomly selected from the seventeen villages that make up Oyigbo L.G.A. Descriptive statistical tools, such as frequency and percentages were used in analyzing the data. Results showed that majorities $(65.6 \%)$ of the cassava farmers were above 51 years which implied that able bodied young men and women were scarcely available for farm work. The result further showed that about $50 \%$ of the farmers received only primary education. Most of them rented their farmlands, used old cassava stem cuttings and were scarcely visited by extension agents. It is therefore recommended that adequate infrastructural facilities such as good roads and electricity, etc be made available in the rural areas to reduce the migration of the youths to urban centers in search of non existent white collar jobs. Credit liberalization policy should also be implemented by the Government to enable the farmers increase their farm sizes and purchase improved planting materials. Adult education programmes should be intensified by the Government to raise the educational standards of these farmers. The training of more extension agents is hoped to increase the number of extension contacts among these smallholder cassava farmers.
\end{abstract}

Keywords: Cassava Farmers, Problems, Prospects, Oyigbo.

\section{INTRODUCTION}

Many development oriented policies have been implemented in Nigeria, especially in the agricultural sector since independence. The Federal Government has made some institutional and policy reforms targeted at improving the socio-economic status of the smallholder farmers. These include Agricultural Credit Guarantee Scheme Fund (ACGSF), River Basin Development Authorities (RBDAs), Agricultural Development Programmes (ADP) and the Cassava Multiplication Programme (CMP) and the School to Land Programme mounted by the Rivers State Government. Available reports showed that many aspects of agricultural production, such as cultivation, marketing, processing, etc were covered (ADP, 2005). The Root and Tuber Expansion Programme (RTEP) is an offshoot of the CMP. Nnanna (2010) contended that RTEP is a farmer oriented programme whose beneficiaries are poor households and smallholder farmers but the overall objective of RTEP is to enhance national food self-sufficiency, improve rural households' food security and income for poor farmers within the cassava belt which include the Southern and Middle belt States of Nigeria (Onyeneke, 2008).

Cassava is an important source of dietary carbohydrate, and provides food for over 60 million people in Nigeria (Abdulahi, 2003). Cassava's adaptability to relatively marginal soils, erratic rainfall; its high productivity per unit of land and labour, the certainty of obtaining some yield even under the most adverse conditions and the possibility of maintaining continuity of supply throughout the year (Nweke, 1994), make this root crop a basic component of the farming system in many areas of Nigeria including Rivers State. Famine rarely occurs in areas where cassava is widely grown, since it provides a stable food base to the food production system. Apart from its use as a staple food to human beings other uses include animal feed formulation, agro-industrial uses (e.g. starch, ethanol, adhesive, fructose/glucose syrup), the peels in organo-mineral fertilizers formulation (Ojeniyi, 2001; Akanbi, et.al.; 2006, lyagba, 2010). Cassava has become the magic crop in Nigeria as a result of the Presidential initiative on cassava some years ago with good export potential. 
This shows that cassava possesses the potential of eliminating food crisis and famine.

In order to boost cassava production in Nigeria, the Federal Government and International Fund for Agricultural Development (IFAD) jointly initiated the cassava multiplication Programme with the aim of promoting cassava utilization as a commodity-based approach against food insecurity (Adeniji, 2000). The beneficiary States include Anambra, Akwa-lbom, Benue, Cross- River, Imo, Kwara, Ogun, Ondo, Oyo, Plateau and Rivers States (BNARD, 1990). Despite these efforts, Nigeria is still grappling with the challenges of food insecurity, poverty, and many other socio-economic problems.

Oyigbo Local Government Area (LGA) is one of the Upland areas of Rivers State in Nigeria (NDDC, 2006) where cassava cultivation is predominant. Cassava production provides employment for the inhabitants especially men, women and children. The International Institute of Tropical Agriculture (IITA) has developed a method of using plastic mulch (plasticulture) to increase cassava planting materials and tuber yield. Plastic mulch in crop production conserve soil moisture, improves soil structure through increased earthworm activity, reduced erosion, nutrient leaching and suppression of weeds (Lamont, 1999;). Previous studies (Onuoha, 2004, Ojimba, 2006, Anyanwu, 2006, 2009a, b, and Anyanwu et al 2009) did not indicate problems and prospects of cassava production in Oyigbo L.G.A. Therefore, this study aimed at highlighting the problems and prospects of cassava production in Oyigbo L.G.A., will not only fill this gap in knowledge, but will provide the requisite information needed to sharpen policies geared towards self-sufficiency in cassava production in Oyigbo L.G.A. in particular and Nigeria in general.

\section{METHODOLOGY}

Study Area: Oyigbo L.G.A. is divided into two parts namely Asa and Ndoki. These sections share boundaries with Abia and Cross River States respectively. The mainstay of Oyigbo L.G.A. economy is farming. The two sections are made up of a total of seventeen (17) villages. Multi-stage sampling technique was used in selecting the samples. A total of 6 villages were randomly selected from these 17 villages, namely, Izuoma, Mmiri Nwanyi, Obeama, Oyigbo Urban, Afam Ukwu and Umuagbai. With the assistance of the extension agents in the Local Government Area, the lists of cassava farmers were compiled, and this formed the sampling frame. From each of these villages, 30 cassava farmers were randomly selected from the list of cassava farmers in each village. This gave a total sample size of 180 smallholder cassava farmers. Structured questionnaire and interview schedule were used in the data generation exercise. Data were collected on farm sizes, land acquisition and methods of land preparation, sources of stems, usage of inorganic fertilizer, extension contacts, etc.

Data Analysis: The data were analyzed with the aid of descriptive statistical tools such as means, percentages and frequency tables.

\section{RESULTS AND DISCUSSION}

Age Distribution of Cassava Farmers: Table 1 shows the age distribution of the cassava farmers in Oyigbo L.G.A. The table indicates that majority $(65.6 \%)$ of the cassava farmers were above 51 years. The implication of this result is that able bodied young men and women were no longer interested in cassava farming. Swaminathan (1986) argued that lack of rural infrastructure and low prices for produce were the primary reasons why able bodied and qualified people felt reluctant to engage in farming. This will negatively impact on labour availability, cost of production and low cassava productivity.

Table 1: Ages Distribution of Cassava Farmers in Oyigbo L.G.A

\begin{tabular}{|l|c|c|}
\hline Age (Years) & Frequency & Percentage \\
\hline Below 20 & 16 & 3.3 \\
\hline $21-30$ & 8 & 4.4 \\
\hline $31-40$ & 12 & 6.7 \\
\hline $41-50$ & 36 & 20 \\
\hline $51-60$ & 56 & 31.1 \\
\hline Above 60 & 62 & 34.5 \\
\hline Total & 180 & 100 \\
\hline
\end{tabular}

Level of Education of Cassava Farmers in Oyigbo L.G.A.: Table 2 showed that $50 \%$ of the cassava farmers attended primary school, $24.4 \%$ were illiterates, and $17.8 \%$ attended secondary school while only $7.8 \%$ attended post secondary schools. The result showed that majority $(50 \%)$ of the cassava farmers received only primary education which implies that these farmers did not receive enough education to enable them grapple with the challenges inherent in modern farming. This result is however, at variance with NDDC (2006) that argued that the population of the Niger Delta comprises strong local communities and a significant proportion of welleducated young people $(43.3 \%$ attend primary 
schools and $13.5 \%$ attend universities). Acquisition of education is a measure of skill which enhances the recipient's chances of success in any chosen field. It increases people's accessibility to institutionally related services such as extension or credit facilities. Anyanwu et al. (2012) has shown that increase in the educational level of smallholder cassava farmers will result in increase in their orientation towards cassava production for the market or commercialization index. Poorly educated farmers tend to be very conservative as they resist new innovations. The net effect of this poor level of education is continuous adoption of old farming practices with the associated vicious cycle of low productivity.

Table 2: Level of Education of Cassava farmers

\begin{tabular}{|l|c|c|}
\hline $\begin{array}{l}\text { Level of } \\
\text { Education }\end{array}$ & Frequency & Percentage \\
\hline $\begin{array}{l}\text { No formal } \\
\text { education }\end{array}$ & 44 & 24.4 \\
\hline Primary & 90 & 50 \\
\hline Secondary & 32 & 17.8 \\
\hline Post Secondary & 14 & 7.8 \\
\hline Total & 180 & 100 \\
\hline
\end{tabular}

Farm Sizes of Cassava Farmers: Increases in farm sizes have been reported to lead to increase in the gross income of cassava farmers in Burkina Faso and Senegal (Reardon et al., 1997), Rivers State (Anyanwu, 2009, Anyanwu and lyagba, 2009) and Imo State (Obasi, 2005) in Nigeria. Table 3 showed that $45.6 \%$ of the farmers cultivated farm sizes within the range of $2-3$ hectares, while only $15.5 \%$ cultivated farm sizes that are above 3 hectares. This result showed that majority of the farmers cultivated small farm holdings. Strong (1989) stated that the average land holdings of small scale farmers were often too small for efficient land utilization. With the direct correlation between farm sizes and gross income, it implies that small farm sizes will naturally lead to low cassava output and low productivity.

Table 3: Distribution of Farm sizes of cassava Farmers in Oyigbo L.G.A.

\begin{tabular}{|l|c|c|}
\hline $\begin{array}{l}\text { Farm sizes } \\
\text { (Hectare) }\end{array}$ & Frequency & Percentage \\
\hline Less than 1 & 4 & 2.2 \\
\hline $1-1.99$ & 66 & 36.7 \\
\hline $2-2.99$ & 82 & 45.6 \\
\hline $3-3.99$ & 24 & 13.3 \\
\hline Above 4 & 4 & 2.2 \\
\hline Total & 180 & 100 \\
\hline
\end{tabular}

Systems of Land Acquisition: In Oyigbo L.G.A., farm lands may be acquired through renting, inheritance, leasing or outright purchase. Table 4 showed that $55.5 \%$ of the cassava farmers acquired their farm lands by renting, $21.1 \%$ through inheritance, while $11.2 \%$ purchased their farm lands. The Niger Delta Region where Oyigbo L.G.A of Rivers State is located is one of the poorest parts of the developing world where per capita income is very low $\{66 \%$ of the population earn less than N10, 000 (approx. US\$75) per month and $76.6 \%$ earn less than $\mathrm{N} 20,000\}$. The incidence of poverty is very high with over $70 \%$, living at subsistence level in rural areas (NDDC, 2006). The implication of this result is that since majority of the cassava farmers rented their farm lands and given the claims of NDDC (2006), with respect to the financial predicament of the Niger Delta people, their capacity to rent large areas of land for cassava farming becomes doubtful. This will definitely limit the existing local capacity not only for cassava but also for food production in general.

Table 4: Systems of Land Acquisition

\begin{tabular}{|l|c|c|}
\hline $\begin{array}{l}\text { Systems of land } \\
\text { acquisition }\end{array}$ & Frequency & percentage \\
\hline Inheritance & 38 & 21.1 \\
\hline Renting & 100 & 55.5 \\
\hline Buying & 20 & 11.2 \\
\hline Leasing & 22 & 12.2 \\
\hline Total & 180 & 100 \\
\hline
\end{tabular}

Sources of Stem Cuttings: Planting materials has been reported as one of the most important determinants of productivity (Crawford, 1993). Occasionally seeds and seedlings have not been sufficient to meet the needs of the farmers, or the preferred species have not been available. This makes it necessary for farmers to fall back on the use of local or unimproved varieties whose productivities are generally low. Lack of planting materials is a limitation to adoption of agroforestry in Southern Africa (Kwesiga et al., 2003). Plant breeding programmes have developed improved cultivars that have increased productivity or maintained productivity in the face of worsening environmental conditions. Table 5 showed that in Oyigbo L.G.A., majority of the cassava farmers $(47.8 \%)$ relied on their previous year's cassava stem cuttings while $2.2 \%$ got theirs from the Ministry of Agriculture. This scenario will impact negatively on cassava production not only in the Local Government Area but also in the country at large. This result agrees with the findings of Anyanwu et al (2012), who reported a non 
significant but positive correlation between cassava stem cuttings and Household commercialization index of cassava farmers in Rivers State, Nigeria.

Table 5: Sources of Stem Cuttings

\begin{tabular}{|l|c|c|}
\hline Sources & Frequency & Percentage \\
\hline Other Farmers & 22 & 12.2 \\
\hline $\begin{array}{l}\text { Previous years } \\
\text { plantings }\end{array}$ & 86 & 47.8 \\
\hline $\begin{array}{l}\text { Ministry of } \\
\text { Agriculture from }\end{array}$ & 4 & 2.2 \\
\hline $\begin{array}{l}\text { Purchased } \\
\text { the market }\end{array}$ & 68 & 37.8 \\
\hline Total & 180 & 100 \\
\hline
\end{tabular}

Extension Contacts: Extension contact has been shown to be a statistically significant explanatory variable determining the adoption of technologies such as soil conservation technologies (MatthewsNjoku et al., 2009). Table 6 showed that $84.5 \%$ of the cassava farmers were not visited by extension agents while $4.4 \%$ were visited once every month. Such poor extension contacts deprive farmers of access to information on latest research findings and experience which are supposed to be converted to field accomplishments. Inadequate extension contact with farmers has negative effect on farmers' productivity.

Table 6: Extension Contacts with Cassava farmers.

\begin{tabular}{|l|l|l|}
\hline $\begin{array}{l}\text { Period of } \\
\text { Visits }\end{array}$ & Frequency & Percentage \\
\hline Weekly & - & - \\
\hline Monthly & 8 & 4.4 \\
\hline Yearly & 20 & 11.1 \\
\hline No Visit at all & 152 & 84.5 \\
\hline Total & 100 \\
\hline
\end{tabular}

Credit Sources to Cassava farmers: The role of financial resources as a factor of production to induce economic growth and development as well as need to channel these resources to the agricultural sector of the economy for economic empowerment cannot be overemphasized. Credit availability and the efficiency of their utilization in the smallholder farming systems are two sides of the same coin. If credit is available but cannot be accessed by the smallholder farmers due to the existence of structural rigidities in credit administration, then the needed economic development will not be realized (Anyanwu, 2011). It has been argued that restricted access to finance, dearth of agricultural inputs, inefficient market systems and continued use of traditional agricultural techniques are among the factors responsible for low agricultural growth and development (Omanukwue, 2007). Table 7 showed that $54.5 \%$ of the cassava farmers obtained their credit from thrift societies, $35.5 \%$ used their personal money, 5.5\% borrowed from money lenders, while only $4.5 \%$ obtained bank loans. With this scenario among these farmers, their low productivity becomes a fait accompli. The importance of farm credit necessitated the various reforms in the financial sector of the Nigerian economy in the 1990s, ostensibly to increase accessibility of credit to smallholder farmers. While Njoku et al (1991) argued that success in this direction has been limited, CBN (2003) claimed that although these reforms have redressed to a considerable extent, the abuses inherent in credit rationing, the issue of inadequate accessibility by farmers has persisted. This implies that cassava productivity in this Local Government Area will be hampered by inadequate credit necessitating production at subsistence level.

Table 7: Credit Sources to Cassava Farmers in Oyigbo L.G.A.

\begin{tabular}{|l|c|c|}
\hline Source & Frequency & Percentage \\
\hline Personal & 64 & 35.5 \\
Thrift societies & 96 & 54.5 \\
Money lenders & 10 & 5.5 \\
Bank loans & 8 & 4.5 \\
\hline Total & 180 & 100 \\
\hline
\end{tabular}

Prospects of Cassava Production in Oyigbo L.G.A.: Cassava production, processing and marketing have a significant social and economic role to play in most developing countries including Nigeria of which Oyigbo L.G.A. is a part. The crop is perceived as a catalyst for development because of its contribution to food security, poverty alleviation, improvement in income distribution and gender equity (Henry, 2000).It is a basic staple food crop for 500 million people in tropical and sub-tropical parts of the world and one of the most reliable and cheapest sources of food (IFAD and FOA, 2000). Cassava market in Oyigbo L.G.A., is attractive. A study by Fuglie (2002) related to cassava use showed that cassava is a competitive crop, especially for the production of starch and animal feed. The use of cassava from 1993-2020 is predicted to increase by around $1.74 \%$ per annum in the Asian region.

By using better planting materials, increasing the level of education, accessibility to credit and increased extension contacts, the productivity of cassava is expected to increase. 


\section{CONCLUSION AND RECOMMENDATIONS}

This study examined the problems and prospects of cassava production in Oyigbo L.G.A. Multistage sampling technique was used in the data generation exercise. Six (6) villages were randomly selected from the seventeen villages that make up Oyigbo L.G.A. The lists of cassava farmers from these villages formed the sampling frame. From the list of cassava farmers in each of these villages, fifteen (15) cassava farmers were randomly selected. Structured questionnaire were used in eliciting responses from the farmers. Descriptive statistical tools, such as frequency and percentages were used in analyzing the data. Results showed that majority $(65.6 \%)$ of the cassava farmers were above 51 years which implied that able bodied young men and women were no longer interested in cassava farming. The result further showed that about $50 \%$ of the farmers received only primary education. The net effect of this level of education will be continuous adoption of old farming practices with the associated vicious cycle of low productivity. The farm sizes of majority of these farmers were small. Most of them rented their farmlands, used old cassava stem cuttings and were scarcely visited by extension agents.

It is therefore recommended that adequate infrastructural facilities such as good roads and electricity, etc be made available in the rural areas to reduce the drift of the youth to urban centers in search of non existent white collar jobs. Credit liberalization policy should be implemented by the Government to enable the farmers increase their farm sizes and purchase improved planting materials. Adult education programmes should be put in place by the Government to raise the educational standards of these farmers. The training of more extension agents is advocated, in order to increase the number of extension contacts among these smallholder cassava farmers.

\section{REFERENCES}

Abdulahi, Abubarkar (2003). Employment Creation and Opportunities in the Agro-Allied Sub-Sector; The Case of Cassava Production. The Bullion Publication of CBN 27 (4): $1-10$

Adeniji, A. (2000). National seed series, Cassava Multiplication Project, Paper presented on root and tuber development in Nigeria, 1-8.

Agricultural Development Programme (2005). Annual report of the Abia State Agricultural Development Programme, Umuahia, Abia State, Nigeria, p.36.
Akanbi, W.B., Adeboye C.O., Togun A.O., Ogunride,J.O. and Adeyeye, S.A. (2007). Growth, herbage and seed yield and quantity of Telfairia occidentalis as influenced by cassava peel compost and mineral fertilizer. World Journal of Agricultural Science. 3(4): 508-516

Anyanwu, S.O. (2006): A Comparative Cost Analysis of Yam and Cassava Production In Emohua L.G.A. A Case Study of Ndele Community, Interdiscip. J. of Research Initiators, 2 (2):15-26.

Anyanwu, S.O. (2009a). Gender and Resource Productivity among Small-Scale Food Crop Farmers in Rivers State, Nigeria, Global Approaches to Extension Practice (GAEP) 5 (1): 107-114.

Anyanwu, S.O. (2009b). Resource Productivity and Economic Efficiency among Farm Credit and Non Farm Credit Users in Rivers State, Nigeria, J. of Technology and Education in Nigeria, 14(1 \& 2): 1120.

Anyanwu, S.O. and G. A. lyagba (2009). Resource productivity and Efficiency among Cassava Farmers in Rivers State, Nigeria, J. of Agric. Forestry, and the Soc Sc. 7 (1): 1-11.

Anyanwu, S.O. (2011). Production efficiency among Farm Credit and Non Farm Credit Users in the Smallholder Farming Systems of Rivers State, Nigeria, Journal of Agricultural Science (India), 2 (2): 127-135.

Anyanwu, S.O., A.E.Kalio, H.A.Manilla, and T.P. Ojimba (2012). Cassava Commercialization and its Determinants in Rivers State, Nigeria Journal of Agricultural Science, India (in press)

Benue State Agricultural and Rural Development Authority (1990). Baseline survey of root and Tuber crops production, processing and storage of bye products in Benue State, Makurdi, pp.44.

Central Bank of Nigeria (2003). Contemporary Economic Policy Issues in Nigeria. In Nnanna, O.J., Alade, S.O and Odoko, F. O. (eds). Kas Arts Services, Nigeria.

Fuglie, K.O. (2002). Economic Prospects For Root and Tuber Crops for Starch and Animal Feeds in Asia. Progress in Potato and Sweet Potato Research, Indonesia. (CIP ESEA and IAARD.

Henry, G. (2000). Global Cassava End Uses and Market, Production, Perspective and Future Prospects FAO Bulletin, Rome, No. 85. PP. 242

IFAD and FAO, (2000). Cassava can play a key role in Reducing Hunger and Poverty Press Release 00/25, Rome, April, 26th.

lyagba, A.G. (2010). A review on root and tuber crop production and their weed management among small scale farmers in Nigeria. APRN Journal of Agricultural and Biological Science. 5(4): 52-58. 
Kwesiga, F., F.K. Akinnifesi, P.L. Mafongoya, M.H. McDermott, and A. Agumya (2003). Agroforestry research and development in southern Africa during the 1990s: Review and challenges ahead. Agroforestry Systems, 59(3):173-186.

Lamont, C. (1999). Vegetable Production Using Plasticulture: Food Fertilizer Center Extension Bulletin, No. 476.

Matthews-Njoku, E., D.Ohajianya, C. Nwachukwu,, E.U. Onweremadu and C.C. Asiabaka (2009). Determinants of Adoption of Cover Cropping Technology: An Application of Multivariate Logistic Analysis in Imo State, Nigeria, lloeje, M.U., C.C.Asiabaka, J.C. Obiefuna, G.E.Osuji, A.B.I. Udedibie, J.S.Orebiyi, M.C.Offor, B.O.Esonu, G.E.Nwandikom, N.J.Okeudo, and E.B. Etuk ( eds)., Proceedings of the International Conference on Global Food Crisis: Theme, Global Food Crisis: The Way Forward, Fed. Univ. of Techn. Owerri, Nigeria. pp. 387-392.
Ojeniyi, E.T. (2001). Processing and economics of production of lesser known Cassava food products in South-Western Nigeria. In: Akoroda, M.O. and Ngeve, J.M. (Eds). Root crops in the $21^{\text {st }}$ Century. Proc. of the Int. Soc. For Tropical Root Crops - Africa Branch (ISTRC-AB). October 11-17, 1998. pp. 126-131.

Ojimba, T. P. (2006). Crop Farmers' Socio - demographic Characteristics in crude Oil Polluted and Non Polluted Farmlands in Rivers State, Nigeria. Journal of Voc. Education. and Technology, 3: 87- 97.

Omanukwe, P. (2007). Agricultural Knowledge Systems, Information and Communication technologies and their implications for agricultural development in Nigeria, Bullion Publication of Central Bank of Nigeria, 31: 3138.

Onuoha, K.M. (2004). Oil exploration and production in Nigeria, recent Developments and challenges ahea, the postgraduate school, Univ. of Ibadan.

nyyeneke, V.E. (2008). Assessing impact of cassava technologies on rural poverty in Imo State using sustainable livelihoods framework" PhD Thesis,(Unpublished) Dept. of Agric. Econs. Michael Okpara Univ. of Agriculture, Umudike, Umuahia,

Niger Delta Development Commission (NDDC) (2006). Niger Delta Regional Development Master Plan NDDC, 167 Aba Rd Port Harcourt, Nigeria, pp. 97.

Njoku, J. and M.A.C.A. Odii (1991). Determinants of Loan Repayment under the Special Emergency Loan Scheme (SEALS) in Nigeria: A Case Study of Imo State. African Review of Money, Finance and Banking, Milano, Italy, No.1, 39-52.

Nweke, F.I. (1994). Processing Potentials for Cassava Production growth in Africa, COSCA Working Paper No. 11, Collaborative Study of Cassava in Africa, IITA, Ibadan

Obasi, P. C. (2005). Application of Trans Log Function to Productivity Estimation in Imo State, Nigeria Int. J. Agric. Rural Dev. SAAT FUTO Owerri, $6: 26-33$.
Reardon, T. V. Kelly; E. Crawford, T. Jayne, K.Savadogo and D. Clay (1997). Determinants of Farm Productivity in Africa: A Synthesis of Four Case Studies. Technical Paper No. 75, SD Publication Services. Office of Sustainable Development Bureau for Africa. U.S. Agency for International Development USAID. Pp1-42.

Strong, M.F. (1989). Ending Hunger Through Sustainable Development. African Farmer Bulletin, No.2, pp.46.

Swaminathan, M.S. (1986). Sustainable nutrition security for Africa: Lessons from India. The Hunger Project Papers, No. 5, pp.11-12. 